\title{
A keleti és nyugati régiók nyelvföldrajzi összehasonlítási lehetőségeiről a nyelvatlaszok alapján*
}

1. Bevezetés. A 20. században az első, később atlasz formában megjelent nyelvatlaszunk gyüjtésének kezdetétől, 1948-tól 2011-ig 22 nyelvatlaszunk ${ }^{1}$ jelent meg. Előadásomban csak az egész magyar nyelvterületet átfogó kutatóponthálózattal rendelkező nagyatlasszal, az öt erdélyi és a tizenkét dunántúli, pontosabban a Duna észak-déli vonalától nyugatra fekvő 11 dunántúli és egy felvidéki atlasszal fogok foglalkozni.

Mely atlaszok tartoznak ide? A Duna észak-déli vonalától nyugatra fekvő területek tizenkét atlasza: Az állathangutánzó igék, hívogatók és terelők somogyi nyelvatlasza (ÁllSA.), a Hangutánzó igék vasi és muravidéki atlasza (HVMA.), a Horvátországi (szlavóniai) magyar nyelvjárási atlasz (SzlavA.), A jugoszláviai Baranya magyar tájnyelvi atlasza (JBarA.), A jugoszláviai Muravidék magyar tájnyelvi atlasza (MurA.), A kisalföldi kocsik és szekerek szakszókincsének nyelvatlasza és szótára (KKSzASz.), A Nyitra-vidéki magyar nyelvjárások atlasza (NyvA.), az Ormánsági nyelvatlasz (OrmAm.), az Örségi és hetési nyelvatlasz (ÖHA.), a Sárvíz menti nyelvatlasz (SMA.), a Somogy-zalai nyelvatlasz (SZA.) és a Zselici nyelvatlasz (ZsA.). Az öt erdélyi atlasz: A romániai magyar nyelvjárások atlasza 1-11. kötete (RMNyA.), A moldvai csángó nyelvjárás atlasza 1-2. kötete (CsángA.), a Hétfalu nyelvjárási atlasza (HétfA.), a Székely nyelvföldrajzi szótár (SzNySz.) és a Szilágysági nyelvatlasz (SzilA.); valamint A magyar nyelvjárások atlasza 6 kötete (MNyA.).

Külön magyarázatot két atlasz kíván. Elsőként az erdélyi területröl A romániai magyar nyelvjárások atlasza, melynek anyaga mostantól, a 11. kötet megjelenésétől emelhető be teljes egészében a vizsgálatokba. A másik TEMESI MiHÁLY Ormánsági nyelvatlasza, mely csak részletekben, ez idáig két kiadványban (TEMESI 1965, 2002) látott napvilágot. TEMESI MIHÁLY összesen mindig „közel 200” térképlapot említ (TEMESI 1965: 146, 154; 2002: 16, 22), azonban PESTI JÁNOS közléséből ${ }^{2}$ tudjuk, hogy a jelenleg hozzáférhetőkön kívül megszerkesztett állapotban nincsen több. Jelenleg az atlasz körülbelül harmada, 76 térképlap érhető el, ezért OrmAm. ( $m$ mint mutatvány) rövidítés alatt lehet jelölni és bevonni a rendelkezésre álló adatokat az egyesítés munkálataiba.

* Az Egy elkészült és egy készülő magyar nyelvatlasz - kutatási tapasztalatok és perspektívák címü konferencián 2011. november 23-án elhangzott előadás szerkesztett, bővített változata.

${ }^{1}$ Az előadás óta eltelt időszakban újabb nyelvatlaszok láttak napvilágot, melyek a következők: Medvesalja magyar nyelvjárási atlasza (MedvA.), Nyugat-bácskai magyar nyelvatlasz (NybA.), valamint a Változó nyelvhasználat a hármas határ mentén címü munka keretében a hármas határ atlasza (HHNyH.).

${ }^{2}$ JUHÁSz DEZső szíves szóbeli közlése alapján. 
Előadásomban e tizennyolc atlasszal fogok foglalkozni, ezek összehasonlítási lehetőségeit próbálom összegyüjteni és néhány kiemelt szempont szerint bemutatni.

A nyelvatlaszok általános, rendszerezett feldolgozása egyelöre nem történt meg, aminek a legfontosabb oka részben az, hogy a bennük található valószínüleg már több mint egy milliónyi adat feldolgozása hagyományos módon nem oldható meg. Megoldást a digitalizálás, az informatizálás, és az ezek segítségével a különböző igényeknek megfelelően rendszerezhető és előállítható térképlapok jelentenek.

Az idő előrehaladtával, az újabb és újabb atlaszok megjelenésével egyre több adatból válogathatunk, és az egyre több adat között egyre nehezebb a kapcsolatokat és az összefüggéseket megtalálni. Éppen ezért, mint általánosan meghatározó tényezővel, az időbeliséggel kezdem az összehasonlítási lehetőségek ismertetését.

2. Az időbeliség. Az első vizsgálandó szempont az időbeliség. Mikor gyüjtötték az atlasz anyagát, illetve mikor adták ki a kötetet? Nagyon fontos, hogy meg kell különböztetnünk e két dátumot, ugyanis nemegyszer előfordul - jó példa erre éppen A romániai magyar nyelvjárások atlasza vagy a Zselici nyelvatlasz -, hogy $20-30$, vagy akár több mint 40 év is eltelik az adatok gyüjtése és a nyelvatlasz kiadása között.

\section{1. táblázat}

A nyelvatlaszok gyüjtéseinek ideje

\begin{tabular}{|l|l|}
\hline \multicolumn{1}{|c|}{ Atlasz } & \multicolumn{1}{c|}{ Gyüjtés ideje } \\
\hline OrmAm. & $1948-1949$ \\
\hline CsángA. & $\begin{array}{l}1949-1959, \text { ell. } \\
1962\end{array}$ \\
\hline MNyA. & $\begin{array}{l}1950-1960, \text { ell. } \\
1960-1964\end{array}$ \\
\hline ŐHA. & $1952-1957$ \\
\hline SzNySz. & $\begin{array}{l}1954-1965, \text { ell. } \\
1957 \text { és 1967 }\end{array}$ \\
\hline RMNyA. & $1957-1967$ \\
\hline MurA. & 1960. aug. \\
\hline ÁllSA. & $\begin{array}{l}1960 . \text { okt. } 28 .- \\
1965 . \text { márc. } 15 .\end{array}$ \\
\hline SzlavA. & 1960, 1970, 1980 \\
\hline
\end{tabular}

\begin{tabular}{|l|l|}
\hline \multicolumn{1}{|c|}{ Atlasz } & \multicolumn{1}{c|}{ Gyüjtés ideje } \\
\hline JBarA. & $1961-1962$ \\
\hline ZsA. & $\begin{array}{l}\text { 1963. jan. }- \\
1969 . \text { szept. }\end{array}$ \\
\hline HétfA. & 1970 \\
\hline SzilA. & 1971-1975 \\
\hline \multirow{3}{*}{ HVMA. } & $\begin{array}{l}\text { KÖBÖLKUTI: } \\
1977-1984\end{array}$ \\
\cline { 2 - 2 } & GUTTMANN: . a. \\
\hline SZA. & 1980-1984 \\
\hline NyvA. & 1991 \\
\hline SMA. & $1992-1994$ \\
\hline KKSzASz. & $\begin{array}{l}\text { n. a., kiadva: } \\
1985\end{array}$ \\
\hline
\end{tabular}

Ha vizsgálatokat alapozunk az atlaszokban foglalt adatokra, például összehasonlítjuk két atlasz vonatkozó térképlapját annak érdekében, hogy követni tudjuk, mi hogyan változott a kettő között eltelt idő alatt, mindig a gyüjtési, és nem az atlasz kiadási idejét kell szem előtt tartanunk. A táblázat csak a konkrét gyüjtési 
időket tartalmazza, tehát azokat, amikor az atlaszba kerülő adatokat gyüjtötték; ennek köszönhetően lehet a legelső az Ormánsági nyelvatlasz.

Az adatok alapján látszik, hogy gyüjtési idő szempontjából élesen elkülönül egymástól a nyugati és a keleti régió. Míg nyugaton 1948-tól 1994-ig történtek gyüjtések, addig az erdélyi területen ez az 1970-es évek közepére le is zárult. Ennek külső és belső okai egyaránt vannak. Köszönhetően viszont annak, hogy ezek az atlaszok a gyüjtők személye, képzettsége, a kérdőívek és a gyüjtött adatok feldolgozása szempontjából is sokkal egységesebbek, mint a magyarországiak, jobban is vizsgálhatók, könnyebben és nagyobb biztossággal egybevethetők.

3. A gyüjtés helye. A második fö szempont a gyüjtés helye, vagyis annak rendszerezése, hogy mely területeket ölelik fel a nyelvatlaszok. A legnyugatabbra fekvő kutatópont az ausztriai Felsőorr, míg legkeletebbre a moldvai Bogdánfalva fekszik. E kettő között e 18 atlaszban összesen 1409 kutatópont található, mely az azonosak egybevonása után 1293-ra csökken.

A nagyatlasz-kisatlasz felosztás szerint nagy-, és a legnagyobb területet átfogó atlasz a 395 kutatóponttal rendelkező MNyA., amelynek kutatópontjai Magyarországon kívül öt országot (Jugoszlávia, Ausztria, Csehszlovákia, Szovjetunió és Románia ${ }^{3}$ ) és az összes magyar megyét érintik. JUHÁsz DEZSŐ csoportosítását (JUHÁSz 2007) követve a nagyatlasz után csökkenő sorrendben A romániai magyar nyelvjárások atlasza következik 136 kutatóponttal, majd a 100 kutatópont körüli, a Székely nyelvföldrajzi szótárban feldolgozott székely atlaszok csoportja következik. Ezekhez a dunántúliak közül egyedül a Somogy-zalai nyelvatlasz sorakozik fel a maga 99 településével. A következő egységként meghatározott, 50 körüli települést érintő csoportban már több atlasz vizsgálódik. Tekintélyes méretünek mondható a Szilágysági nyelvatlasz 67, és a BALOGH LAJOS és KIRÁLY LAJOS 60 helységet érintő somogyi állathangutánzó, állathívogató, -terelő kifejezéseket rendszerező atlasza, valamint a vele szomszédos területen gyüjtő, csak 4 kutatóponttal elmaradó Zselici nyelvatlasz. Félszáz kutatópont alatt egy kevéssel az Örségi és hetési nyelvatlasz következik, majd az ormánsági tájatlasz, végül a csoportot A moldvai csángó nyelvjárás atlasza zárja 43 kutatóponttal. Az egyesítésben részt vevő 18 nyelvatlaszból nyolc ennél kisebb: a kocsik és szekerek szakszókincsének célatlasza 34 kisalföldi településen gyüjt adatokat, majd hármas holtversenyben 26-26 kutatóponttal a nyugati részen legnagyobb határon túli, a Dunától már északra vizsgálódó Nyitra-vidéki nyelvatlasz, a vasi és muravidéki hangutánzó igék célatlasza és a legtöbb járulékos szempontot is jelölö, vagyis zárójelekkel minősített nyelvi adatot felsorakoztató SAJTOS-féle atlasz következik. A sor végére PENAVIN OLGA három határon túli nyelvatlasza jut 20, 11, illetve 10 kutatóponttal - sorrendben a muravidéki, a horvátországi (szlavóniai) és a jugoszláviai (horvátországi) Baranya területén adatokat gyüjtők -, majd a listát legkisebbként a Hétfalu nyelvjárási atlasza zárja.

Az egyesített kutatópont-hálózat elkészítésének előfeltételeként minden atlasz minden településének nevét és sorszámát, valamint szükség esetén a további

\footnotetext{
${ }^{3}$ Az országok megnevezésénél az atlaszokban található formát követem.
} 
járulékos információkat be kell gépelni egy táblázatkezelő programba az atlaszok kutatópontjegyzékére vagy ennek hiányában egy térképlapra támaszkodva. A 18 atlasz közül 13 esetben ezt a feladatot én végeztem el, az MNyA. és az erdélyi atlaszok adatait HEGEDÜS ANDREÁtól kaptam meg, és a továbbiakban az engedélyével használom.

A táblázat feltöltése során az atlaszokban közölt írásformára hagyatkozás önmagában nem elegendő, mert helyhiány (pl. OrmAm.), írógépelt lejegyzés (pl. KKSzASz.), vagy akár egy véletlen elírás következtében is előfordul, hogy nem a települések kodifikált megnevezését rögzíti az atlasz. Helyhiányra példa az ormánsági atlasz 32-es kutatópontja, a térképen D.csepely, írógépelt lejegyzésből fakadó ékezet-problémákra a KKSzASz. Dőr és Ujkér alakja. Az egyesített kutatóponthálózatban előbbi esetben egy utaló mutat a kodifikált megnevezésre, D.csepelyről Drávacsepely-re, mert ekkor az azonosítás érdekében szükséges a teljes alak ismerete, míg az ékezetek eltérő alakjából fakadó eltérés a megértést nem nehezíti, ezért elég javítani. A települések számbavételekor többször szembesülünk azzal, hogy egy atlasz valamely kutatópontjának sorszámához több település is tartozik. Ilyen például a HVMA. 22-es kutatópontja, Felsö- és Alsólakos, és az ormánsági atlasz 42-es sorszáma, Rónádfa és Gyöngyfa. A muravidéki kutatópontokat bemutató térképen a két falu egy grafikai jelzéshez van kötve, ezért a fenti formában, az és kötőszóval összekötve együtt szerepelnek a táblázatban. Az OrmAm.-beli esetben Rónádfa 1929-es megszünése, beolvadása óta a település hivatalos neve Gyöngyfa, de TEMESI két külön kutatópontként, két külön grafikai jellel jelöli a két település(rész)t, ezért az egyesített táblázatban külön-külön, mindkétszer a 42es sorszámmal szerepelnek. A határon túli települések lokalizációját nehezíti, ha a magyar vagy az idegen nyelvi nevüket nem tudjuk meg az atlaszból, vagy azok a gyüjtés ideje óta megváltoztak. Előbbi esetben a meglévő alakra támaszkodva a hiányzó alakot ki kell keresni a LELKES-féle helységnévszótárból (2011) vagy valamilyen egyéb megbízható forrásból, hogy a táblázat teljes lehessen. A felkutatás és az ellenőrzés során azonban nemcsak a hiányzó alakokra, hanem a gyüjtés óta megváltozott helységnevekre (jellemzően hosszú-rövid ékezetbeli különbségekre, települések egyesítésére) is fény derül, ami utalók létrehozásához vezet.

A kutatópontok száma önmagában nem árul el túl sokat az atlaszról, de meghatározza jellegét, vagyis hogy közreadói minek szánták, mi volt az alapvető céljuk vele. Magyar nyelven VÉGH JÓZSEF foglalta írásba elsőként az Örségi és hetési nyelvatlasz bevezetőjében a nagyatlasz és a táji nyelvatlaszok egymáshoz való viszonyát és feladatkörét. Korábbi francia mintát is követve a későbbiekben követendő ajánlás az volt, hogy a nagy, nemzeti atlaszok igyekezzenek országhatárok nélkül a nyelv minden nyelvjáráscsoportját átfogni, madártávlatból, nagy vonalakban bepillantást engedve a nyelvi változásokba. Ez azonban a mélyebb nyelvi jelenségeket is követni kívánó vizsgálatokhoz kevés. Idézem ezzel kapcsolatban BÁRCZI GÉZÁt: „Ezért a Magyar Nyelvatlaszon kívül szükség van a kisebb, egyegy vidékre szorítkozó, de egészen sürü hálózatú nyelvjárási térképekre, melyek esetleg kevesebb számú jelenséggel, kevesebb fogalomkör szókincsével foglalkoznak, de a szavak és jelenségek megoszlását apróbb részleteikben elénk tárva 
tanulságosan világítják meg a nyelvi elemek küzdelmeit." (ÖHA. 11.) Az ebben a szellemben készült regionális atlaszok vagy más néven tájatlaszok egy-egy szükebb területet, földrajzi, néprajzi vagy nyelvjárási egységet és esetleg a környékét tárják fel teljes sủrüségủ kutatópont-hálózaton, az adott vidékre jellemző nyelvjárási jelenségekre is fókuszálva.

Ennek fényében árulkodó, hogy a nyelvatlaszokban hányszor ismétlödnek a kutatópontok keleten és nyugaton, vagyis hányszor látogatta meg ugyanazt a települést legalább egyszer kutató(csoport). Nézzük meg a két vizsgált területet külön-külön, majd összehasonlítva.

\section{2. táblázat}

A kutatópontok ismétlődése

\begin{tabular}{|l|r|r|r|r|}
\cline { 2 - 5 } \multicolumn{1}{c|}{} & \multicolumn{2}{c|}{ Nyugat } & \multicolumn{2}{c|}{ Kelet } \\
\cline { 2 - 5 } \multicolumn{1}{c|}{} & Településszám & Százalék & Településszám & Százalék \\
\hline Összesen & 564 & $100 \%$ & 576 & $100 \%$ \\
\hline Kétszer & 92 & $16 \%$ & 50 & $8,6 \%$ \\
\hline Háromszor & 4 & $0,7 \%$ & 2 & $0,3 \%$ \\
\hline Ismétlödések & 96 & $17 \%$ & 52 & $9 \%$ \\
\hline
\end{tabular}

Nyugaton 92 település, az összes település 16\%-a szerepel kétszer, négy település háromszor (Mesztegnyő, Somodor, Szilvásszentmárton és Viszák; ez 0,7\%), vagyis az összesen 564 település 17\%-a ismétlődik. Az erdélyi területen alig 50 helység, az összes település 8,6\%-a fordul elő kétszer, és mindössze kettő háromszor (Kászonaltíz és Zágon, ez 0,3\%), vagyis az összesen 576 településből 52, közel 9\% ismétlődik. Ebből is látszik, hogy míg keleten egységesebb a táji megoszlás, a tájatlaszok jobban kiegészítik az ottani „,nagyatlaszt”, A romániai magyar nyelvjárások atlaszát, addig a Dunántúlon készítésükkor nem voltak összefogva a regionális atlaszok, s emiatt nagyobbak az átfedések, és egyúttal a feldolgozatlan területek is. A Duna észak-déli vonalától nyugatra mindenki a szülőföldje, vagy más, számára valamilyen okból kedves vagy kézenfekvő tájegységen gyüjtött, míg az erdélyi területen a kiválasztás tudatosabban folyt. 1955-ben a Román Tudományos Akadémia kolozsvári Nyelvtudományi Intézete kutatási tervfeladataként tüzte ki egy romániai nagyatlasz elkészítését, majd később a kisebb, táji atlaszok a nyelvészeti tanszék feladatává váltak, aminek következtében egységesebb, központosítottabb volt az atlaszok készítése, mint nálunk. S ez sokkal egyenletesebb minőséghez és könnyebb egyesíthetőséghez vezetett.

4. A gyưjités. Ha megvan a vizsgálatra kijelölt terület, a következő fontos állomás a gyüjtő személye és a gyüjtés módja. A regionális nyelvatlaszokra jellemző az egygyüjtős gyüjtési mód, szemben a több gyüjtöre építő, kutatócsoport(ok) tagjainak együttmúködésével életre hívott nagyatlaszokkal. Az egygyüjtős módszer sikeressége a gyüjtőn és az adatközlőn, illetve a közöttük lévő kapcsolaton 
múlik; a gyüjtött anyag akkor lesz ideális, ha a gyüjtő anyanyelvjárásában, lehetőleg rokonok, ismerösök körében gyüjt. Ez természetszerüleg nem mindig kivitelezhető, de a gyüjtés során az atlaszok készítői a lehetőségeikhez mérten törekedtek a megvalósítására.

A Dunántúl és a Felvidék 13 nyelvatlasza esetében TEMESI, RÓNAI, SÁNDOR, KIRÁLY, SAJTOS és TIMAFFY tudott lakóhelyének, szülőfalujának és annak környékén rokonok, ismerősök körében is adatokat gyüjteni, ki egymaga, illetve családi segítséggel (pl. TEMESInek ormánsági születésü felesége, TOMANÓCZY JOLÁN segített, az adatok érvényességének ellenőrzésében pedig segítségére volt az ormánsági nyelvjárást anyanyelveként beszélő anyósa), ki pedig egyetemi, föiskolai hallgatók bevonásával. A hallgatókkal kapcsolatban RóNAI megjegyzi ( ZsA. 18), hogy a gyakorlógyüjtést végző hallgatók jellemzően a regionális köznyelvhez közel álló változatot, nemegyszer magát a regionális köznyelvet jegyezték le a helyi nyelvjárás még élő jelenségei helyett, továbbá feljegyzetlenül maradtak a paraszti müveltséganyag funkciótlanná vált elemei. Ha feltételezzük, hogy precízen, megbízhatóan dolgoztak a hallgatók, ez a tény az adatgyüjtő személyének fontosságára hívja fel a figyelmünket: minél kevesebb kritériumban felel meg az optimális „anyanyelvjárás gyüjtése otthon; rokonok, ismerősök között” kívánalomnak (KISS 1973), a gyüjtött nyelvi adatokat annál körültekintőbben kell kezelni. Ez egyúttal azt is jelenti, hogy hallgatókkal végeztetett gyüjtés esetében fokozottan szükség van a gyüjtésben részt vevő hozzáértő közremüködőkre és megfelelő, lehetőleg a nyelvjárást anyanyelveként beszélő ellenőrzést végző személyekre.

Az erdélyi területen más a helyzet. Általánosan ismert tény, hogy 1958-1959ben a nagyatlasz gyüjtőinek, BENKÖ LORÁNDnak és LŐRINCZE LAJOSnak félbe kellett hagynia az erdélyi gyüjtést, de a nagyatlasz kérdőíve benne van az RMNyA.ban, közel azonos időben is lettek kikérdezve, illetve MURÁDIN LÁSzLÓ közléséből tudjuk, hogy lejegyzési szempontjaik, sőt még a „fülük is össze volt hangolva”. Idézem MURÁDIN LÁSZLÓt: „Számomra igen megnyugtató volt az is, hogy mikor 1959 nyarán Benkő Loránd és Lőrincze Lajos kísérőjeként figyelemmel kísérhettem A magyar nyelvjárások atlasza számára 9 erdélyi faluban végzett gyüjtőmunkájukat, tapasztalhattam, hogy az ők és a magam gyüjtő-, hallás- és lejegyzési módszere között lényegbeli eltérés nincs, nagymértékben egyező. Az MNyA. gyüjtőinek és a magam lejegyzési gyakorlatának megnyugtató egységét bizonyította az a tény is, hogy mikor összevetettem az időközben megjelent MNyA. erdélyi adatait a magam gyüjtötte adatokkal, egy-egy helyi nyelvjárás hangváltozat-rendszerének összképe egyező volt." (RMNyA. 1: 7.) Ennek köszönhetőn ez a két atlasz szépen összeilleszthető lenne, s továbbgondolva, az összefüggések ismeretében kijelenthetö, hogy az erdélyi kisatlaszokkal is ez a helyzet.

Ennek kapcsán érdemes megemlíteni, hogy kik a nyelvatlaszok s ze rz ő i, milyen foglalkozást üznek, üztek. Kivétel nélkül nyelvészek vagy a nyelvészethez valamilyen szállal kötődő kutatók, egyetemi vagy főiskolai tanárok, de van közöttük egy középiskolai tanár is, SAJTOS JÓZSEF. Ebböl arra is lehet következtetni - azon túl, hogy milyen szintü képzettséget, mennyi és milyen szerteágazó ismereteket követel meg egy nyelvatlasz elkészítése -, hogy a munkálatok stabil intézményi hátteret kívánnak, amely befogadja és támogatja a kutatást. 
5. A címszavak. A keleti és nyugati régiók összehasonlítási lehetőségeinek legfontosabb színtere az egyező címszavakra vagy hangtani, alaktani jelenségekre épülő vizsgálat. Az egyesített címszójegyzék megmutatja, hogy mely címszó mely atlasz hányadik térképlapján szerepel; segítségével könnyen visszakereshetők a címszavak; egy helyen, rendszerezett formában megtaláljuk az azonos denotátumot feldolgozó térképlapokat.

Az egyesített táblázatban a címszavak lelőhelyét az atlaszbeli sor- vagy térképszámuk adja meg, ez teszi őket egyértelmüen azonosíthatóvá. Amennyiben nem térképezett egy vizsgált címszó, de a szerző kutatópontonként részletes leírásban közli, hogy hol milyen alakváltozat(ok) fordul(nak) elö, a címszó a sorszámával együtt bekerül az egyesített táblázatba. Nem térképezett címszavak a 18 egyesített nyelvatlasz közül KIRÁLY LAJOS két nyelvatlaszában (SZA. és ÁllSA.) és a Székely nyelvföldrajzi szótárban fordulnak elő. A SZA.-ban az 1-125-ig terjedők (ami az összes térkép 36,5\%-a), és az ÁllSA.-ban 78\%-os arányban, összesen 182-szer. A SzNySz. mind a 894 térképlapja térképezetlen, de tekintettel arra, hogy szótárról lévén szó a címszavak megtalálhatók a betürendi helyükön, nem kell jelölni, hogy hányadik oldalon található a kötetben. Az egyesített mutatóban ez esetben csak egy X szerepel.

A címszavak egyesítésekor a nyelvatlaszok címszómutatóját, vagy ennek hiányában a térképlapokon kiemelt címszót vettem alapul. A két hangutánzó, hívogató, terelő kifejezéseket rendszerező dunántúli regionális célatlasz esetében azonban az általános mutatón felül nem készült egy elsődleges változatokat tartalmazó címszómutató, és az egyes térképlapokon (vagy adattárban közölt, a kutatópontokon előforduló variánsokat felsoroló gyüjteményben) sem emelnek ki egy egyértelmü azonosításra alkalmas alakváltozatot. Ezért a két célatlaszban található 433 térképlap csak címszavasítás után (l. SzABÓ 2010,2012) kerülhetett be a vizsgálatokba.

A nyelvatlaszok címszavainak egyesítési módszeréről és nehézségeiről HEGEDŰS ANDREA előadásában hallottunk (1. jelen számban 163-171), ezért részletesen nem térek ki rá. Azonban az nálam is helytálló, hogy minden várakozással ellentétben a címszavak állományának egyesítése és a teljes mutató elkészítése sokkal inkább nagy körültekintést és sok szempont figyelembevételét igénylö, mintsem mechanikus feladat volt.

Mielőtt rátérnék a konkrét számokra, ismét VÉGH JÓZSEFet kell idéznem, aki már 1959-ben lefektetvén a regionális nyelvatlaszokkal kapcsolatos munkálatok elméleti alapjait, tett egy ajánlást a kikérdezendő címszavak milyenségére: „A magyar nyelvatlasz munkaközössége is - függetlenül a franciák elgondolásától 1952-ben úgy döntött, hogy a táji nyelvatlaszok anyagának nagyobb része közös legyen. Úgy tervezte, hogy egy-egy táji nyelvatlasz kb. 150-160 kérdést tartalmazzon, ebből közös törzsanyag 100 legyen, ötvenet-hatvanat pedig az atlasz készítöje jelöljön ki területe sajátos nyelvi viszonyainak bemutatására. A magyar nyelvatlasz munkaközössége ugyanis az MNyA. készítésével nem tekinti befejezettnek a magyar nyelvatlaszmunkálatokat. Kívánatosnak tartja, hogy legalábbis a fontosabb nyelvjárási egységekről (de később talán az egész magyar nyelvterületről) készüljenek táji nyelvatlaszok. Ezen elgondolás alapján indokolt a táji nyelvatlaszok közös törzsanyaga, hogy össze lehessen őket vetni. De már vitatható a táji nyelvatla- 
szokban a törzskérdések és a helyi kérdések aránya." (ÖHA. 52). Nyelvatlaszaink címszómutatóit megnézve látszik, hogy a regionális atlaszok kétharmada fölé ment e kívánt értéknek, és 200 feletti kikérdezett címszóval dolgozott. Ez mindenképpen örvendetes abban az esetben, ha van egy mag, az érintetlenül maradt törzsanyag, amely mintegy önálló rétegként mindegyik atlaszban szerepel.

Nézzük meg A romániai magyar nyelvjárások atlaszának a nyugati atlaszokkal közös címszavait egy kicsit részletesebben.

\section{3. táblázat}

Az RMNyA. és a nyugati atlaszok címszavainak egyezése

\begin{tabular}{|l|r|r|}
\hline \multicolumn{1}{|c|}{ Elöfordulás } & \multicolumn{1}{c|}{ Címszó } & \multicolumn{1}{c|}{ Százalék } \\
\hline Egyszer & 2139 & $64,88 \%$ \\
\hline Kétszer & 696 & $21,11 \%$ \\
\hline Háromszor & 249 & $7,55 \%$ \\
\hline Négyszer & 98 & $2,97 \%$ \\
\hline Ötször & 47 & $1,43 \%$ \\
\hline Hatszor & 27 & $0,82 \%$ \\
\hline Hétszer & 14 & $0,42 \%$ \\
\hline Nyolcszor & 11 & $0,33 \%$ \\
\hline Kilencszer & 5 & $0,15 \%$ \\
\hline Tízszer & 1 & $0,03 \%$ \\
\hline
\end{tabular}

Az RMNyA. 3297 címszava közül mindössze 10 nem szerepel a nyugati nyelvatlaszokban, a nagyatlaszt is beleszámítva. A leggyakrabban elöfordulók a következők: kilenc atlaszban 5 címszó - boritólevél (kukoricáé), csalán, fészektojás, kenyér és töpörtyü) -, tíz atlaszban pedig csak egy, a cicerél (kakas). A jelentősen többször előforduló címszavak kivétel nélkül a paraszti élet szókincsébe tartozó kifejezések, melyek általánosan elterjedtek és a mindennapokban használatosak, s melyek egyöntetüen részét képezik a regionális atlaszok törzsanyagának. Mindezt csak példaképpen mutattam be; az egyesített táblázatok adatait felhasználva még számtalan csoportosítást, az adatokra alapozva pedig jóval mélyebb kutatásokat lehet végezni.

6. Kitekintés. Az előzőekben néhány kiemelt szempont szerint felvillantottam a nyugati és keleti nyelvatlaszok tulajdonságait, ismérveit az idő- és a térbeliség, a gyüjtők és feldolgozók személye, illetve az atlaszban foglalt adatok egyesíthetösége kapcsán. Előadásom zárásaként röviden szeretnék kitérni arra, hogy milyen további lehetőségek rejlenek, és elsősorban épülhetnek az ilyen irányú kutatásokra.

A saját magam elé kitüzött rövidtávú cél a teljes magyar mutatók elkészítése. A 13 dunántúli és felvidéki atlasz egyesítésével az egyesített kutatóponthálózathoz 564, a címszó-mutatóhoz 2505 egyedi tétellel járultam eddig hozzá. 
Az erdélyi atlaszokat is számolva jelenleg 18 atlasz egyesítése van készen, de a közeljövőben szeretnék végezni az összes magyar nyelvatlaszt felölelő egyesített kutatópont-hálózat és címszómutató összeállításával. ${ }^{4}$

A dialektológia oldaláról tekintve természetesen eddig is lehetett vizsgálódni, például lexikai szinten, egy-egy atlaszban megnézve, merre, milyen formában terjedtek a szavak, s ebből nyelvjárási, nyelvtörténeti vagy népiségtörténeti következtetéseket lehetett levonni; vagy összehasonlító vizsgálatokat is lehetett végezni, például két kiválasztott településen gyüjtött adatokat egymás mellé állítva. Ezek mellett születtek átfogóbb, már hangtani vagy morfológiai jelenségekre fókuszáló kutatások is, de az utóbbi időben ezek már rendszerint digitalizált adatokat használtak fel. S csak ezen a vonalon elindulva, a digitalizálás előnyeit kihasználva juthatunk el az egyik általános célig, addig, hogy az atlaszokon átívelő egyesítésnek, majd átfogó vizsgálatoknak köszönhetően kiderülhessen, nyelvileg hogyan és miben kapcsolódnak egymáshoz az atlaszokban feldolgozott területek.

Kulcsszók: atlaszegyesítés, A romániai magyar nyelvjárások atlasza, egyesített címszójegyzék, egyesített kutatópont-hálózat, nyelvatlasz, nyelvföldrajz.

\section{Hivatkozott irodalom}

ÁllSA. = BALOGH LAJOS - KIRÁLY LAJOS 1976. Az állathangutánzó igék, hivogatók és terelök somogyi nyelvatlasza. Akadémiai Kiadó, Budapest.

CsángA. = A moldvai csángó nyelvjárás atlasza. $1-2$. Szerk. GÁLfFY MózES - MÁRTON Gyula - SzABÓ T. ATTILA. Magyar Nyelvtudományi Társaság, Budapest, 1991.

DEME LÁsZló - IMRE SAMU szerk. 1975. A magyar nyelvjárások atlaszának elméletimódszertani kérdései. Akadémiai Kiadó, Budapest.

HEGEDÜS ANDREA 2008. Nyelvföldrajzi vizsgálatok a romániai magyar nyelvterületen az egyesitett atlaszok felhasználásával. Doktori disszertáció. ELTE BTK, Budapest.

HEGEDÜS ANDREA 2016. Egy romániai magyar virtuális nyelvatlasz címszó-egyesítési kérdéseiről. (L. a jelen számban: 163-171.)

HétfA. = Hétfalu nyelvjárási atlasza . Szerk. VöÖ IsTVÁN. Babes-Bolyai Tudományegyetem, Kolozsvár, 1971.

$\mathrm{HHNyH} .=$ Változó nyelvhasználat a hármas határ mentén: többdimenziós nyelvföldrajzi térképlapok tanúságai. Szerk. P. LAKATOS ILONA. Segédkönyvek a nyelvészet tanulmányozásához 146. Tinta Könyvkiadó, Budapest, 2012.

HVMA. = GUTTMANN MIKLÓS - KÖBÖLKUTI KATALIN 1987. Hangutánzó igék vasi és muravidéki atlasza. A Magyar Nyelvtudományi Társaság Kiadványai 182. Magyar Nyelvtudományi Társaság, Budapest.

JBarA. = PENAVIN OLGA 1969. A jugoszláviai Baranya magyar tájnyelvi atlasza . Újvidéki Egyetem, Újvidék.

JUHÁsz DEZsö 1997. A romániai magyar nyelvjárások atlaszának kiadástörténeti, nyelvi és településtörténeti tanulságaiból. Magyar Nyelv 93: 199-207.

${ }^{4}$ A 2011-ben kitüzött célt szem elött tartva, a munkálatokba az időközben megjelenteket is bevonva jelenleg 24 magyar nyelvatlasz egységes szempontok szerint egyesített kutatópont-hálózatának és címszójegyzékének mutatója van készen (1. SZABÓ 2015). 
JuHÁSZ DEZSŐ 2001. A nyelvföldrajz. In: KISS JENŐ szerk., Magyar dialektológia. Osiris Kiadó, Budapest. 92-110.

JuHÁSZ DEZSÖ 2007. Két dél-dunántúli nyelvatlaszról. Magyar Nyelv 103: 96-101.

KISS JENŐ 1973. A nyelvjárások változásáról és az anyanyelvjárási gyűjtésről. Magyar Nyelvör 97: 217-228.

KISS JENŐ szerk. 2001. Magyar dialektológia. Osiris Kiadó, Budapest.

KKSzASz. = TIMAFFY LÁsZLÓ 1985. A kisalföldi kocsik és szekerek szakszókincsének nyelvatlasza és szótára. Magyar Csoportnyelvi Dolgozatok 22. ELTE Magyar Nyelvtörténeti és Nyelvjárási Tanszék - MTA Nyelvtudományi Intézet, Budapest.

LELKES GYÖRGY 2011. Magyar helységnév-azonositó szótár. Argumentum Kiadó - KSH Könyvtár, Budapest.

MedvA. = Cs. NAGY LAJOs 2011. Medvesalja magyar nyelvjárási atlasza. Luminosus n. o. Kiadó, Nagykapos.

MNyA. = A magyar nyelvjárások atlasza 1-6. Szerk. DEME LÁSzLÓ - IMRE SAMU. Akadémiai Kiadó, Budapest, 1968-1977.

MurA. = Penavin Olga 1966. A jugoszláviai Muravidék magyar tájnyelvi atlasza. A Magyar Nyelvtudományi Társaság Kiadványai 116. Magyar Nyelvtudományi Társaság, Budapest.

MurÁDIN LÁSZLÓ 1995. Bevezető. In: RMNyA. 1: 5-8.

NybA. = SILLING ISTVÁN 2012. Nyugat-bácskai magyar nyelvatlasz. Forum Könyvkiadó Újvidéki Egyetem Magyar Tannyelvü Tanítóképző Kar, Újvidék-Szabadka.

NyvA. = SÁNDOR ANNA 2004. A Nyitra-vidéki magyar nyelvjárások atlasza. Mercurius könyvek. Kalligram Kiadó, Pozsony.

ÖHA. = VÉGH JÓZSEF 1959. Örségi és hetési nyelvatlasz. Akadémiai Kiadó, Budapest.

RMNyA. = A romániai magyar nyelvjárások atlasza $1-11$. Gyüjtötte és a kéziratot összeállította MuRÁdIN LÁSZLÓ. Szerk. JUHÁSz DEZSÖ. [1-2.] Magyar Nyelvtudományi Társaság, [3-11.] Magyar Nyelvtudományi Társaság - Pharma Press Kiadó, Budapest, 1995-2010.

SMA. = SAJTOS JózSEF 2004. Sárvíz menti nyelvatlasz. A Magyar Nyelvtudományi Társaság Kiadványai 220. Magyar Nyelvtudományi Társaság, Budapest.

SZA. = KIRÁlY LAJOS 2005. Somogy-zalai nyelvatlasz. A Magyar Nyelvtudományi Társaság Kiadványai 223. Magyar Nyelvtudományi Társaság, Budapest.

SzABÓ PANNA 2010. Az atlaszegyesités néhány kérdése a nyugati magyar nyelvterület dialektológiai atlaszai alapján. Szakdolgozat. ELTE BTK, Budapest.

SzABÓ PANNA 2012. Az atlaszegyesítés lexikográfiai-filológiai kérdései a nyugati magyar nyelvterület nyelvatlaszai alapján. In: PARAPATICS ANDREA - CSERNÁK-SzUHÁNSZKY DEBÓRA szerk., Félúton 7. A hetedik Félúton konferencia (2011) kiadványa. ELTE BTK Nyelvtudományi Doktori Iskola, Budapest. SzP1-SzP15. http://[-] hdl.handle.net/10831/8267 (2016. 07. 04.)

SZABÓ PANNA 2015. Pillanatkép a nyelvatlaszok egyesítési háttérmunkálatainak állásáról. In: BÁRTH M JÁNOS - BOdó CSANÁD - KoCSIS ZsuzSANNA szerk., A nyelv dimenziói: Tanulmányok Juhász Dezsö tiszteletére. ELTE Magyar Nyelvtudományi és Finnugor Intézet - Magyar Nyelvtudományi Társaság, Budapest. 221-228. 
SzilA. = Szilágysági nyelvatlasz. Gyüjt. MÁRTON GYULA, szerk. HeGEdüs ATTILA. A Pázmány Péter Katolikus Egyetem Magyar Nyelvészeti Tanszékének Kiadványai 3. Magyar Nyelvtudományi Társaság - PPKE, Piliscsaba-Budapest, 2000.

SzlavA. = PENAVIN OLGA 1984. Horvátországi (szlavóniai) magyar nyelvjárási atlasz. Magyar Nyelv, Irodalom és Hungarológiai Kutatások Intézete, Újvidék.

SzNySz. = Székely nyelvföldrajzi szótár. Összeáll. GÁlfFY MózES - MÁRTON GYULA, szerk. KISS JENÖ. Akadémiai Kiadó, Budapest, 1987.

TEMESI MiHÁLY 1965. Mutatvány az Ormánság nyelvatlaszából. A Pécsi Tanárképzö Föiskola Tudományos Közleményei 9: 141-171.

TEMEsi MiHÁLy 2002. Az Ormánság nyelvjárása 1939 és 1949 között. Dialóg Campus Kiadó, Pécs.

ZsA. = RÓNAI BÉLA 1993. Zselici nyelvatlasz. Nyelvföldrajzi vizsgálatok a Zselicben. Magyar Történelmi Társulat Dél-dunántúli Csoportja - Magyar Nyelvtudományi Társaság, Pécs-[Budapest].

\section{On the possibilities of comparing the Eastern and Western regions on the basis of language atlases}

The paper discusses eighteen of the twenty-two Hungarian language atlases published between 1948 and 2011: The Atlas of Hungarian Dialects based on a network of collection sites covering the whole Hungarian-speaking area, as well as five Transylvanian and eleven Transdanubian atlases as well as one from Felvidék (Slovakia). First, atlases of the Eastern and Western regions are compared according to their time of collection and publication, showing that in Transylvania, they were produced relatively simultaneously while in Transdanubia they were published during a rather long period of time. The coverage and overlap features of the two regions can be studied via perusing the collection sites of the large versus regional atlases; percentages of coincidence show that collection work for regional atlases complementing the national atlas was conducted more watchfully and in a better-planned manner in the Eastern region. With respect to the collection of linguistic data, the selection of fieldworkers and a uniform methodology of collection are of prime importance. It is difficult to find detailed data concerning the latter issue, but it seems to be confirmed that the two large atlases and the Transylvanian regional ones were made with a uniform methodology. Coincidences across the headwords of the atlases provide a variety of possibilities for comparison and analysis. In this paper, coincidence percentages of The Atlas of Hungarian Dialects in Romania and the atlases of the Western region are compared. Among other conclusions, it is shown that The Atlas of Hungarian Dialects in Romania has only ten headwords that are not included in any of the western atlases.

Keywords: linguistic geography, language atlas, merging of atlases, aggregate headword list, The Atlas of Hungarian Dialects in Romania.

SZABÓ PANNA

Eötvös Loránd Tudományegyetem 